This item was submitted to Loughborough's Research Repository by the author.

Items in Figshare are protected by copyright, with all rights reserved, unless otherwise indicated.

\title{
Butler and electrocrystallisation
}

PLEASE CITE THE PUBLISHED VERSION

PUBLISHER

(c) Maney Publishing / Institute of Metal Finishing

VERSION

VoR (Version of Record)

LICENCE

CC BY-NC-ND 4.0

REPOSITORY RECORD

Gabe, D.R.. 2009. "Butler and Electrocrystallisation”. figshare. https://hdl.handle.net/2134/4148. 
This item was submitted to Loughborough's Institutional Repository (https://dspace.lboro.ac.uk/) by the author and is made available under the following Creative Commons Licence conditions.

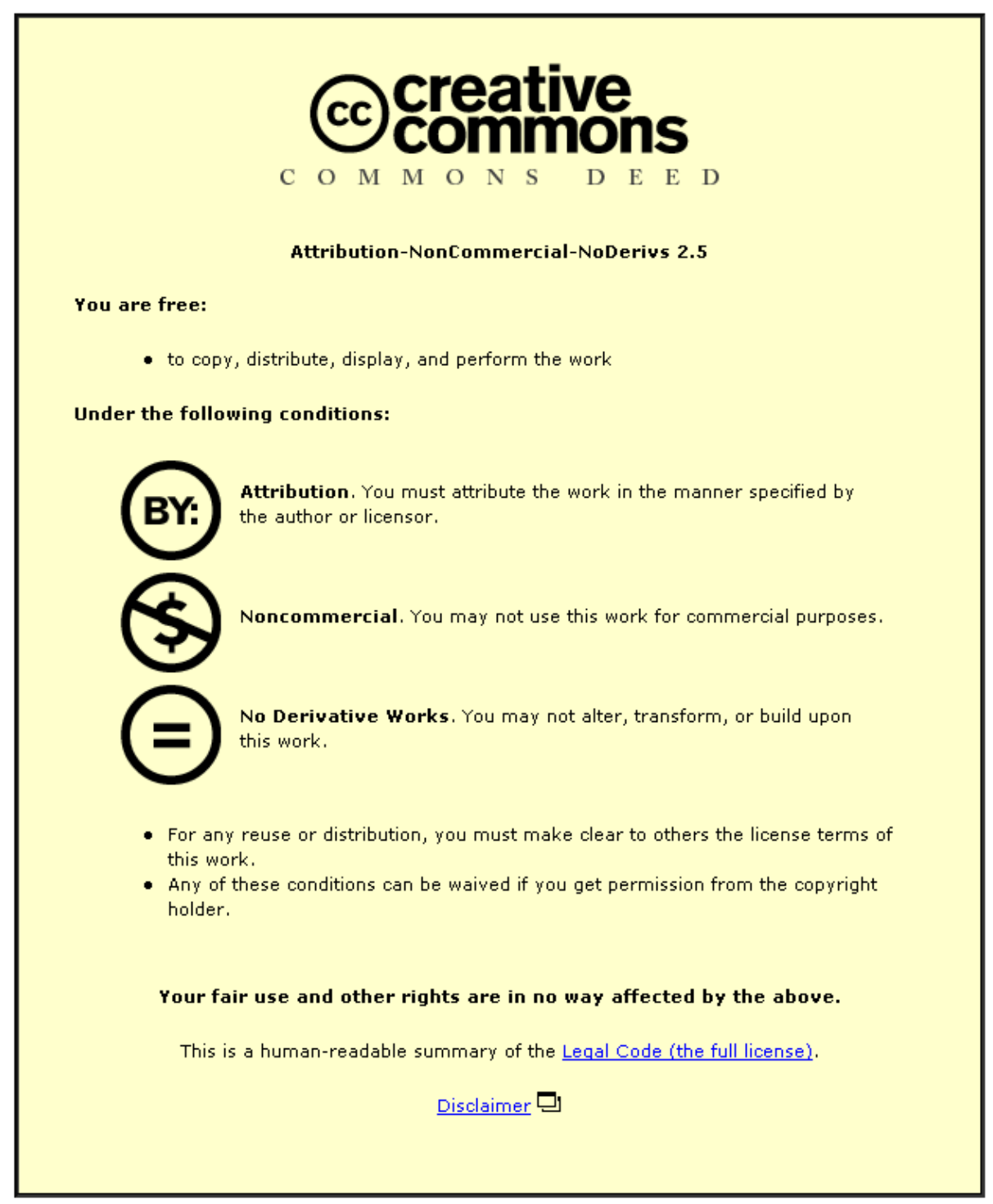

For the full text of this licence, please go to: http://creativecommons.org/licenses/by-nc-nd/2.5/ 


\title{
Butler and electrocrystallisation
}

\author{
D. R. Gabe*
}

It is increasingly unusual for a scientist who is a specialist in a narrow field to make an outstanding contribution in another, albeit adjacent, field. John Alfred Valentine Butler was such a person - a chemist who made a profound contribution to electrode discharge reaction theory almost as an aside from his main work.

Born in Winchcombe, Gloucestershire. on 14 February 1899, he was educated at Cheltenham Grammar School and Birmingham University but, having to join the army in 1917, he was not free to continue his education until 1918, when he studied for his Inter BSc from the army, bought and read Bragg's new book on X-ray crystallography and joined the University in 1919 on an ex-army scholarship, taking a first in 1921. Being too young to receive the degree, he did a year's research with $\mathrm{Dr}$ S. R. Carter on 'A sulphur electrode' from which he later wrote his first paper and gained an MSc degree! He was then,

successively, a lecturer in chemistry at Swansea (1922-1926), and Edinburgh (1926-1939) universities, teaching and researching in chemical

thermodynamics. ${ }^{1}$ This work provided the material for his second textbook which was widely used during the period from 1930 to $1970 .^{2}$ He took his DSc in 1927 and was Meldola Medallist of the Royal Institute of Chemistry in 1929. In 1939, he joined the Rockefeller Institute for medical research at Princeton University where his interests moved from the energetics of electrochemical reactions towards biological and medical aspects of chemistry. In 1941, he became an executive officer at the Commonwealth Scientific Office in Washington, returning to Edinburgh in 1944. In 1946, he moved to the Courtauld Institute for Biochemistry at Middlesex Hospital becoming, in 1952, Professor of Physical Chemistry in London University at the Institute of Cancer

IPTME, Loughborough University, Loughborough, LE11 3TU, UK

*Email d.r.gabe@ |boro.ac.uk

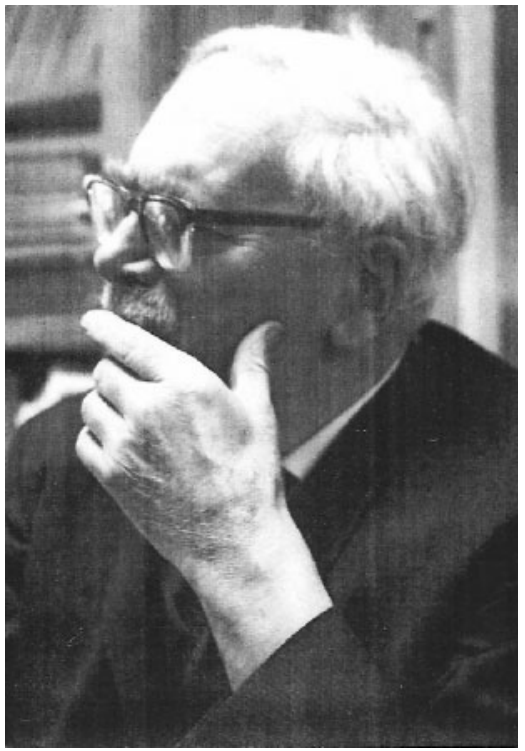

Research. He retired in 1966. His biological interests are represented by other books. $^{3-10}$ (It has often been noted that all his books are characterised by great modesty, such that he does not always make reference to his own important research papers!)

Thus his remaining years were devoted to solution and electrochemical aspects of medical compounds notably DNA and the histones. In fact, from 1946 to 1968, he wrote 140 papers with an especial association with B. E. Conway until he left for Canada in the mid 1950s.

He was elected to the Royal Society in 1956 and died on 16 July 1977, having written over 200 papers and a series of books. He was married to Margaret Lois Hope, the botanist daughter of the Liberal MP for West

Fife and had three children all of whom having good careers. His interests included painting (in the Cezanne/Nan Gogh tradition), music especially Schubert and Mahler, and he was an active Anglican.

During the 1920s as a teacher of thermodynamics he was clearly fascinated by the implications of the Arrhenius equation and activation energies to characterise and describe reaction paths and rates. In particular, he was concerned about the discharge of ions at cathode surfaces to become atoms in the surface metal lattice and the various energetic steps they passed through during the discharge process. Furthermore, he was driven by a need to justify Tafel's experimental equation of $1905,{ }^{11}$ and a desire to explain Nernstian potentials from a kinetic (current) point of view. This resulted in his proposal of an analysis leading to the Butler equation; ${ }^{12,13}$ almost simultaneously Volmer in Germany published a similar analysis and the equation is now termed the Butler-Volmer equation. Other researchers later refined it, notably Erdey-Gruz, ${ }^{14}$ while Butler himself moved on to other topics only returning to it, when invited to, for symposia presentations. ${ }^{15-17}$

Derivation of the equation can be found in all the major textbooks on electrochemistry but it incorporates a number of features of importance. The simple equation is the sum $J$ of the forward and reverse reaction currents

$$
\begin{aligned}
& \mathrm{J}=\mathrm{J}(-)+\mathrm{J}(+)= \\
& \mathrm{J}_{0}\{\exp [\beta \mathrm{nF} \eta / R T]- \\
& \exp [-(1-\beta) \mathrm{nF} \eta / R T]\}
\end{aligned}
$$

In this equation $\mathrm{nF}$ is the Faradaic equivalence, $R$ the gas constant, $T$ temperature, and $\eta$ the overpotential. The important features are:

(i) the concept of reversibility such that the deposition and dissolution reactions are noted. Clearly, at high currents, one dominates to the virtual exclusion of the other

(ii) the concept of multiple activation energy stages in which solvation (or desolvation) is important as is the role of adsorption and adatom surface diffusion to least energy sites; the use of a symmetry factor $\beta$ expresses the skewness of the activation energy-distance curves

(iii) the definition of an exchange current density $J_{0}$ at reversible potential 
(iv) the means of measuring the exchange current density by extrapolation which could characterise the metal and its salt in solution

(v) by making suitable approximations at various levels of overpotential, observed relationships between current and potential could be explained, notably the Tafel relationship of $\eta=a$ $\pm b \ln /$ which had hitherto been an experimental relationship only. ${ }^{11}$ Using the Butler format, the Tafel equation now becomes:

$$
\ln J=\ln J_{0}+\{(1-\beta) \mathrm{nF} / R T\} \eta
$$

The theory of electrocrystallisation has since this time received huge attention and consequent publication listings. In particular, the role of hydrogen as opposed to metal discharge in cathodic electrodeposition processes, and the way in which ions become adatoms and then lattice atoms in the deposit growth process. The need to explain differences in grain size and even crystal structure at differing currents, the effects of surface-active additives, the effects of differing solution anions, and the effect of pulsed current, etc. have all continued to provide a theoretical challenge to the original Butler-Volmer approach which remains the base point.

\section{Acknowledgement}

Permission to publish the portrait photograph was given by the Institute for Cancer Research. Biographical Memoirs of the Royal Society (1979, 25, 145-178) give a full account of Butler's life and work.

\section{References}

1. J. A. V. Butler: 'The chemical elements and their compounds'; 1927, London, MacMillan.

2. J. A. V. Butler: 'Chemical thermodynamics', 1st edn; 1928, London, MacMillan Co.

3. J. A. V. Butler: 'Electrocapillarity: the physics and chemistry of charged surfaces'; 1940, London, Methuen Co.

4. J. A. V. Butler: 'Man is a microcosm'; 1950, London, MacMillan.
5. J. A. V. Butler: 'Science and human life: success and limitations'; 1957, London, Pergamon Press.

6. J. A. V. Butler: 'Inside the living cell'; 1959, London, Allen and Unwin.

7. J. A. V. Butler: 'The life of the cell'; 1964, London, Allen and Unwin.

8. J. A. V. Butler: 'Gene control in the living cell'; 1968, London, Allen and Unwin.

9. J. A. V. Butler: 'The life process'; 1970. New York, Allen and Unwin

10. J. A. V. Butler: 'Modern biology and its human implications'; 1976, London, Hodder and Stoughton.

11. D. R. Gabe: Trans. IMF, 2005, 83, 121-124.

12. J. A. V. Butler: Trans. Faraday Soc., 1924, 19, 729.

13. J. A. V. Butler: Phil. Mag., 1924, 48, 927.

14. T. Erdey-Gruz and M. Volmer: Z. Phys. Chem., 1930, 150, 203.

15. J. A. V. Butler: Trans. Faraday Soc., 1932, 28, 379.

16. J. A. V. Butler: Proc. Roy. Soc. A., 1936, 157, 423.

17. J. A. V. Butler: Z. Electrochem., $1938,44,55$

\section{IMF Education and Training}

Education and Training are two of the most important activities of the Institute of Metal Finishing. Academic programmes have been developed to meet a wide range of requirements from Foundation up to Licentiate level. The content varies from basic general information to specific programmes on organic coatings.

In addition to satisfying the requirements of individuals Bespoke Academic Training Programmes have been developed to meet the needs of companies such as Land Rover, BMW and Seagate (in Ireland) and have been recognised by those companies as having led to significant improvements in the quality of their products. Further, the Automotive Surface Finishing course, as taught at Land Rover and BMW, is the first course to be recognised by the Automotive Academy and given Industry Recognised Status. Other courses and modules are being considered by the Automotive Academy where they have been delivered to automotive manufacturers' 'first tier' suppliers. Bespoke courses are available in other surface finishing areas and the IMF staff at Exeter House will be delighted to advise interested parties on examples of such courses provided through the institute's CORPORATE EDUCATION activities.

A significant investment of time and money has been made to up-date most Distance Learning modules, the Foundation Course has been extended and made more flexible and there is now a Distance Learning version so that people who are unable to attend a tutored course still have the opportunity to study. A new course on Environmental Issues has been developed, and it is proposed to convert this course into a Distance Learning module.

The Technician Certificate can be studied by Distance Learning or a Tutored Route. Student notes are supplied to aid candidates studying for both the Foundation Certificate and the Technician Certificate. The Tutored Programmes can also be offered in different modes to suit company requirements, if studied 'in house'. The IMF's aim is to provide an educational service to individuals and companies.

Please contact Exeter House to discuss your requirements and obtain a copy of the examination regulations document. 